\title{
Sexual dimorphism in morphometric characters of Mystus singaringan from Klawing River in Central Java, Indonesia: Strategic instruction for conservation development
}

\author{
TAUFIK BUDHI PRAMONO ${ }^{1, \bullet}$, DIANA ARFIATI ${ }^{2}$, MAHENO SRI WIDODO ${ }^{2}$, UUN YANUHAR ${ }^{2}$ \\ ${ }^{1}$ Faculty of Fisheries and Marine Sciences, Universitas Jenderal Soedirman. Jl. Prof. Dr. HR Boenyamin No. 708, Purwokerto Utara, Banyumas 53122 , \\ Central Java, Indonesia. Tel./fax.: +62-281-642360, "email: tb1pram@yahoo.com \\ ${ }^{2}$ Faculty of Fisheries and Marine Science, Universitas Brawijaya. Jl. Veteran No. 16, Lowokwaru, Kota Malang 65145, East Java, Indonesia
}

Manuscript received: 27 February 2019. Revision accepted: 25 March 2019.

\begin{abstract}
Pramono TB, Arfiati D, Widodo MS, Yanuhar U. 2019. Sexual dimorphism in morphometric characters of Mystus singaringan from Klawing River in Central Java, Indonesia: Strategic instruction for conservation development. Biodiversitas 20: 1133-1139. This study aims to determine the sexual dimorphism of Mystus singaringan (Senggaringan fish) based on morphometric characters. The measurement of 24 morphometric characters in 30 M. singaringan from Klawing River was carried out using a digital caliper $(0.01$ $\mathrm{mm}$ ). Morphometric data of $M$. singaringan analyzed using t-test have showed significant difference in 12 morphometric characters between sexes, such as standard length, head height, distance of the tip of the muzzle to eyes, distance of the tip of the muzzle to adipose fin, height of dorsal fin, height of pectoral fin, basic length of adipose fin, height of adipose fin, maximum height, length of first nasal barbel, length of first mandibular barbel, and length of second mandibular barbel. Analysis of growth of morphometric characters shows that there is a linear relationship between all morphometric characters and total length. The type of growth of all morphometric characters in both male and female $M$. singaringan is negative allometric.
\end{abstract}

Keywords: Dimorphism, female, indigenous species, Mystus singaringan, male, morphometric

\section{INTRODUCTION}

Bagridae is family to which 205 species of fish belong. The family spreads in Africa and Asia with 45 species from the genus of Mystus spread in East Asia, South Asia, Southwest Asia (Eschemeyer and Fong 2015) and in Indonesia, to be exact in Java, Sumatra, and Kalimantan (Hubert et al. 2015). Fish species from the Bagridae family that can be found in Java is Mystus singaringan or senggaringan fish (Dahrudin et al. 2016; Pramono et al. 2017). M. singaringan have high economic value in the area of Purbalingga District, Central Java, Indonesia. However, senggaringan fish supply is still from wild catch fisheries. This certainly will have an impact on population stability and make senggaringan fish prone to extinction. To prevent its extinction, conservation and domestication are needed. The success of conservation and domestication is influenced by several things including basic biological information related to sexual dimorphism.

Sexual dimorphism is defined as a systemic morphological difference or phenotypic differentiation between individuals from different sexes in the same species that is used to distinguish sexes externally (Dimijan 2005; Saurabh et al. 2013; Suryaningsih et al. 2014). In addition, sexual dimorphism can also be interpreted as the variation of intraspecific phenotype (McGee and Wainright 2013). Sexual dimorphism can be identified from primary sexual characters, namely genital papilla or genital pore (Musa and Bhuiyan 2006; Esmaeili et al. 2017), and from secondary characteristics of color, body size, morphology, physical strength and other body characters (Dimijan 2005), the relation between length and condition factor (Nahar et al. 2018). However, sexual dimorphism of some taxa is often unclear (Levitan 2005) and vague when it is observed by unaided eye (Andersson et al. 1994). Some types of fish sometimes show clear characteristics of sexual dimorphism as spawning period approaches. Therefore, it is necessary to do an easy and authentic initial approach to determine sexual dimorphism.

Sexual dimorphism can be determined using morphometric methods. Detailed examination of morphometric methods is carried out based on morphometric characters or parts of aquatic organism morphological characters, in both the size and shape, by measuring distances of particular external body parts quantitatively (Kim et al. 2008; Maurya et al. 2018). Determination of sexual dimorphism, especially sex differentiation based on morphometric characters, has been done with fairly accurate results, for example, determination of sexual dimorphism on red chick barb or Puntius orphoides (Suryaningsih et al. 2014), European perch or Perca fluviatilis (Ulicevic et al. 2018), and pink skunk clownfish or Amphiprion perideraion (Abol-Munafi et al. 2011). However, until now there has never been informed about sexual dimorphism of $M$. singaringan that is based on morphometric methods.

Understanding on sexual dimorphism is very important and some findings conveyed by sexual dimorphism can give many valuable information, such as the process of receiving signals (Taborsky 1998), social structure and 
adaptation (Kim et al. 2008), change strategies (Shaurabh et al. 2013), rationalization of fishery catch in public waters (Suryaningsih et al. 2014), and choice in parent fish for breeding (Esmaeili et al. 2017), mate and intrasexual competition (Taborsky 1998). This study aims to determine the sexual dimorphism of $M$. singaringan based on morphometric characters. The research of sexual dimorphism of $M$. singaringan is expected to be a useful basis for developing new strategies in the conservation and domestication program of $M$. singaringan.

\section{MATERIALS AND METHODS}

\section{Animal sampling}

Thirty samples of $M$. singaringan (16 males, 14 females) were collected from January to March 2017 from the Klawing River, in Purbalingga District, Central Java. Fish were caught using gill nets. The caught fish were stored in deep-frozen condition and then analyzed for morphometry in the laboratory. Morphometry measurements were carried out using digital caliper 0.01 $\mathrm{mm}$ accuracy with the position of the fish head facing to the left (Suryaningsih et al. 2014).

The measured morphometric characters were total length (TL), standard length (SL), head length (HL), eye diameter (ED), the distance between mouth and eye or periorbital distance (POD), predorsal distance of dorsal fin (PDDF), predorsal distance of adipose fin (PDAF), maximum body height $(\mathrm{BH})$, minimum body height $(\mathrm{bH})$, dorsal fin length (DFL), height of dorsal fin (HDF), pectoral fin length (PFL), height of pectoral fin (HPL), ventral fin length (VFL), height of ventral fin (HVL), anal fin length (AFL), anal fin length (AFL), height of anal fin length (HAFL), base length of adipose fin (BAF), height of adipose fin (HAF), upper barbeus length (UBL1), upper barbeus length (UBL2), bottom barbeus length 1 (BBL1), bottom barbeus length 1 (BBL2), length of caudal peduncle (LCP). After the measurement was done, dissection was performed to determine the sex of the fish.

\section{Statistical analysis}

The obtained data were analyzed statistically using SPSS version 16. The measurement results of all morphometric characters were compared to the total length to see allometric growth patterns. Differences in morphometric characters were analyzed by t-test. Significance of parameter was calculated using t-test at a confidence interval of $95 \%$ and $99.9 \%$ (Zar 1999). Allometric growth, referring to Minos et al. (1995), is calculated using regression analysis based on the function $\mathrm{Y}=\mathrm{aTL}^{\mathrm{b}}$, where ' $\mathrm{Y}$ ' is a morphometric variable, ' $\mathrm{a}$ ' is a constant, and ' $b$ ' is a slope. Allometric growth variable consists of positive allometric $(\mathrm{A}+)$ with slope $\mathrm{b}>1$, negative allometric $\mathrm{b}<1$, and isometric $\mathrm{b}=1$.

\section{RESULTS AND DISCUSSION}

\section{Results}

Data obtained from the measurement of morphometric characters in 30 samples of $M$. singaringan (16 males and 14 females) from Klawing River are presented in Table 1. The total length of female fish ranged from 150-234 mm, and the average length was $196.07 \pm 25.01 \mathrm{~mm}$, while the total length of male fish ranged from 165-204 mm with average length of $182.56 \pm 12.00 \mathrm{~mm}$. In addition, it is revealed that the average value of morphometric characters of female $M$. singaringan is bigger than that of male $M$. singaringan.

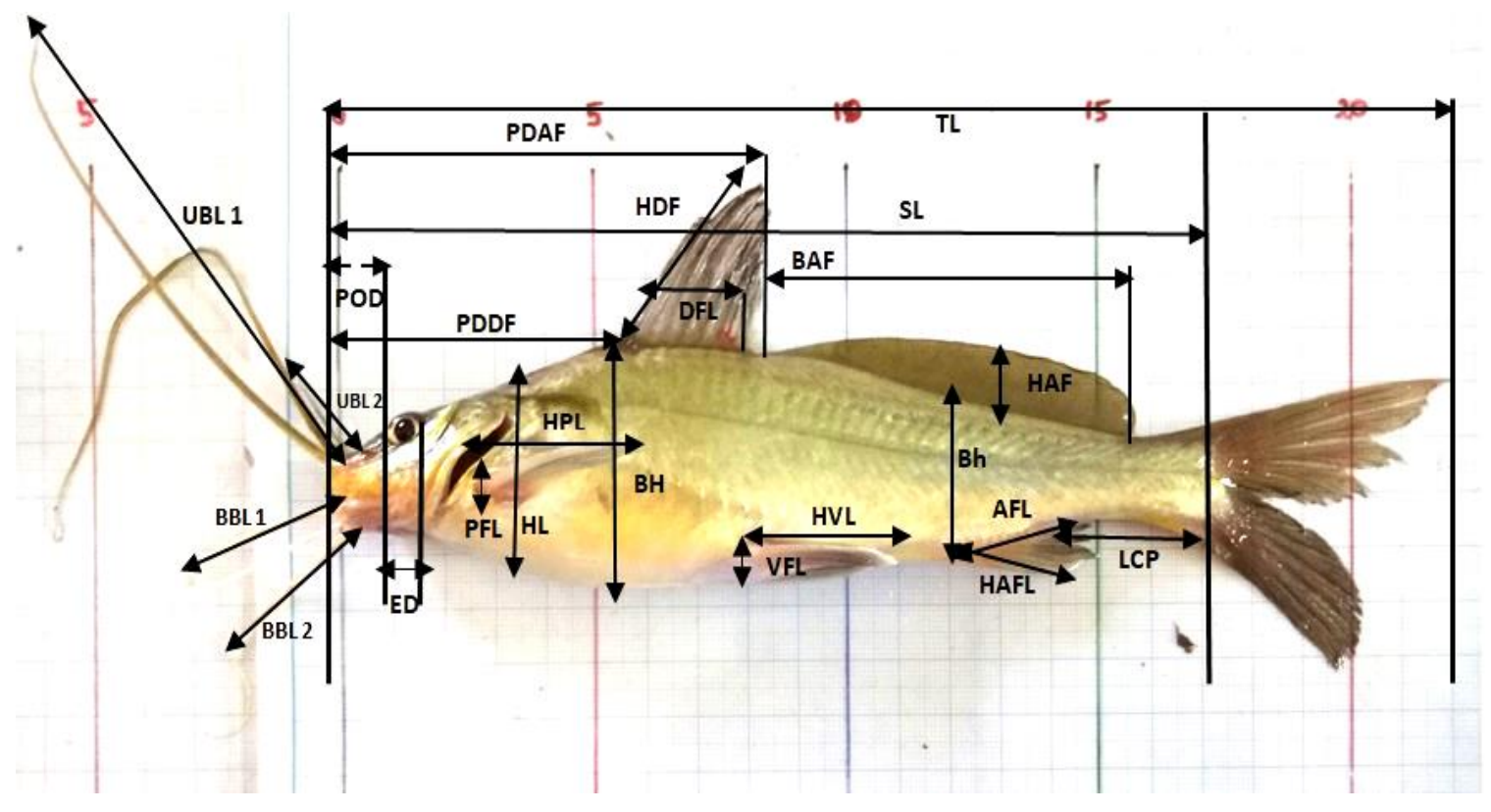

Figure 1. Morphometric measurements of Mystus singaringan 
Based on the results of the t-test, from 24 morphometric characters, there were 12 characters which showed very significant differences $(\mathrm{P}<0.05 ; \mathrm{P}<0.001)$, namely the character of standard length (SL), head height (HL), the distance of the muzzle to the eyes (POD), the distance of muzzle to adipose fin (PDAF), maximum height $(\mathrm{H})$, height of dorsal fin (HDF), height of pectoral fin (HPL), base length of adipose fin (BAF), height of adipose fin (HAF), upper barbeus length (UBL1), bottom barbeus length 1 (BBL1), and bottom barbeus length 1 (BBL2). Meanwhile, other characters, such as total length (TL), eye diameter (ED), predorsal distance of dorsal fin (PDDF), minimum height $(\mathrm{bH})$, dorsal fin length (DFL), pectoral fin length (PFL), ventral fin length (VFL), anal fin length (AFL), height of pelvic fin (HVL), height of anal fin (HAFL), upper barbeus length 2 (UBL2), length of caudal peduncle (LCP), did not show significant differences. Those significantly different characters become discriminator for the sex of $M$. singaringan. Another thing that strengthens the determination is that the measured characters did not show too overlapping values, and vice versa, other characters that are not significantly different had high heterogeneous values. $M$. singaringan dimorphism can be seen in Figure 2.

In this study, the growth of morphometric characters of $M$. singaringan, both male and female, has a linear relation with total length. The growth pattern of all morphometric characters of $M$. singaringan was included in negative allometric category $(\mathrm{b}<1)$, as it is presented in Table 3.

In this study, sexual dimorphism of $M$. singaringan can be determined from 12 significantly different morphometric characters and from 12 other morphometric characters that are not significantly different (Table 2). However, other fish from Bagridae family, such as Mystus pelusius, do not show any different form of sexual dimorphism in terms of body size (Esmaeili et al. 2017), whereas in Mystus gulio, standard length, body depth, and head length become markers for sexual dimorphism of male and female fish (Begum et al. 2008). Those different results indicate that each fish species has different absolute size (Nugroho et al. 2016) and has certain geographical distribution which is controlled by the physical conditions of the environment (Ariyanto and Imro 2008). The size, distribution, and variation of the morphometric characters are supposed to be the adaptation of these fish species to their environment or habitat. Farrag et al. (2015) have emphasized that the influence of environmental interactions can trigger morphometric differences, such as variations in growth, development, and maturation, among species.

\section{Discussion}

Research on sexual dimorphism of fish from other families, as reported by Kim et al. (2008), has found out that in Korean Chub (Zacco koreanus) from Cyprinidae family, out of 37 morphometric characters, there are 12 morphometric characters that are significantly different between male and female fish. The most distinctive morphometric characters $(\mathrm{P}<0.001)$ in Korean Chub or Zacco koreanus is the pectoral fin length (PECL) and the distance between the dorsal fin insertion and insertion of the anal fin (IDF-IAF) (Kim et al. 2008).

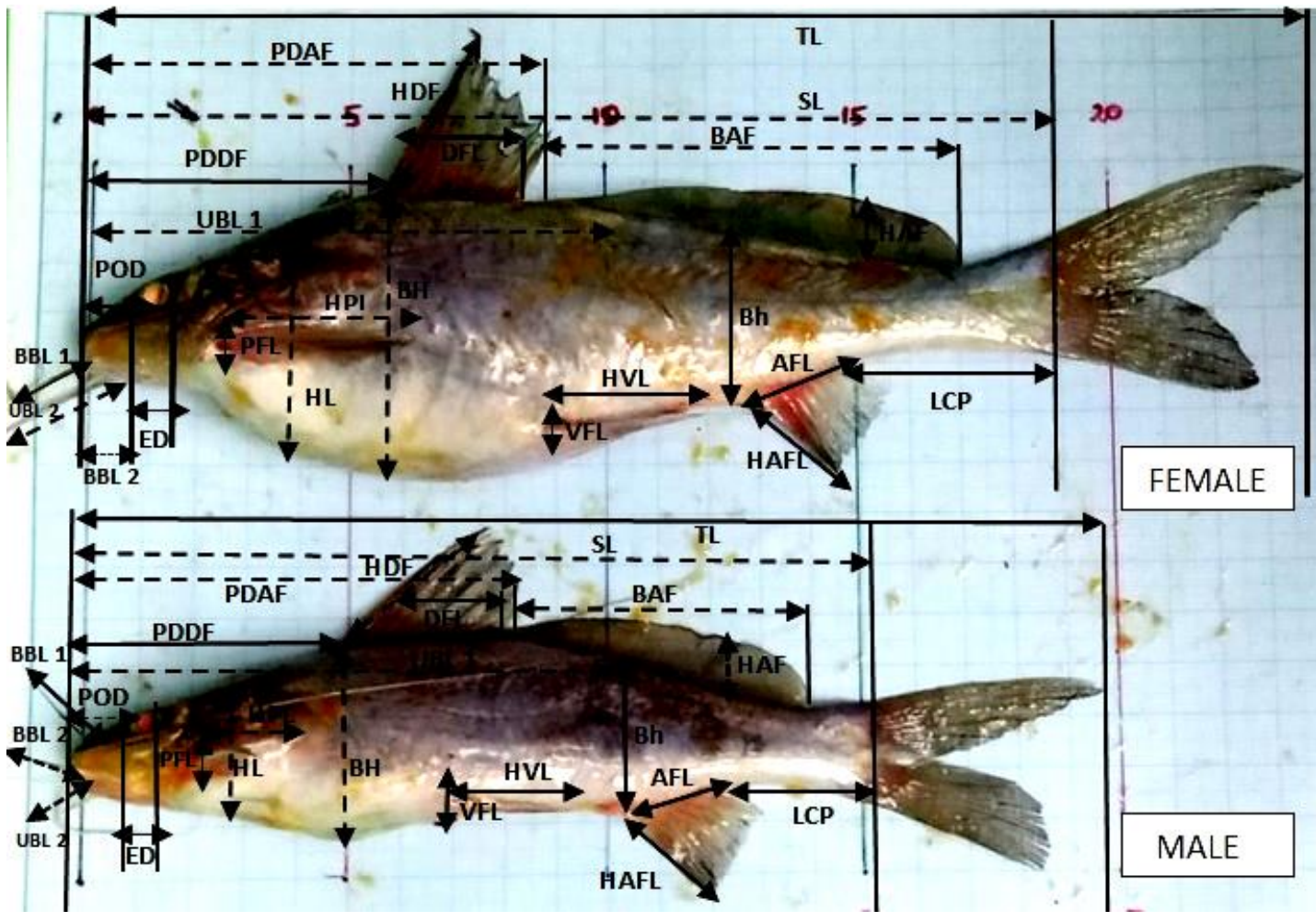

Figure 2. Male and female Mystus singaringan sexual dimorphism 
Table 1. Diagnostic character of Mystus singaringan with references (Aryani et al. 2013)

\begin{tabular}{|c|c|c|c|c|c|c|c|c|c|c|}
\hline \multirow{2}{*}{$\begin{array}{l}\text { Morphometric } \\
\text { character (mm) }\end{array}$} & \multicolumn{5}{|c|}{ Male } & \multicolumn{5}{|c|}{ Female } \\
\hline & $\mathbf{N}$ & $\mathbf{M}$ & Min & Max & SD & $\mathbf{N}$ & $\mathbf{M}$ & Min & Max & SD \\
\hline TL & 16 & 182.56 & 165 & 204 & 12.00 & 14 & 196.07 & 150 & 234 & 25.01 \\
\hline SL & 16 & 139.18 & 128 & 155 & 8.56 & 14 & 153.14 & 123 & 178 & 18.58 \\
\hline HL & 16 & 23.20 & 20.8 & 27.7 & 1.88 & 14 & 37.26 & 27.78 & 53.4 & 8.49 \\
\hline ED & 16 & 5.05 & 4.2 & 6.2 & 0.50 & 14 & 5.04 & 4.1 & 5.9 & 0.46 \\
\hline POD & 16 & 10.89 & 8.2 & 11.92 & 1.02 & 14 & 14.59 & 9.68 & 17.25 & 2.39 \\
\hline PDDF & 16 & 46.52 & 28.1 & 55.92 & 6.76 & 14 & 51.36 & 38.7 & 61.25 & 6.74 \\
\hline PDAF & 16 & 65.22 & 58.14 & 71.2 & 4.02 & 14 & 77.93 & 63.44 & 89.22 & 7.53 \\
\hline $\mathrm{Bh}$ & 16 & 15.71 & 13.38 & 20.9 & 1.91 & 14 & 17.26 & 12.4 & 21.6 & 2.83 \\
\hline $\mathrm{BH}$ & 16 & 30.27 & 26.09 & 36.78 & 3.16 & 14 & 41.74 & 26.9 & 51.55 & 7.28 \\
\hline DFL & 16 & 18.07 & 15.2 & 23.7 & 2.31 & 14 & 19.07 & 16.1 & 24.3 & 2.61 \\
\hline HDF & 16 & 30.25 & 26.2 & 32.8 & 1.99 & 14 & 36.31 & 28.1 & 41.22 & 4.38 \\
\hline PFL & 16 & 5.71 & 4.5 & 7.6 & 0.86 & 14 & 5.50 & 4.4 & 6.3 & 0.62 \\
\hline HPL & 16 & 22.64 & 19.7 & 27.7 & 1.95 & 14 & 24.07 & 14.9 & 30.01 & 4.89 \\
\hline VFL & 16 & 4.36 & 3.35 & 5.8 & 0.69 & 14 & 4.337 & 3.1 & 5.6 & 0.82 \\
\hline HVL & 16 & 24.89 & 19.85 & 28.5 & 2.36 & 14 & 24.07 & 14.9 & 30.1 & 4.89 \\
\hline AFL & 16 & 11.73 & 9.3 & 15.2 & 1.61 & 14 & 12.97 & 10.2 & 16.9 & 2.24 \\
\hline HAFL & 16 & 20.80 & 15.82 & 24.1 & 2.04 & 14 & 19.69 & 10.5 & 23.5 & 3.91 \\
\hline BAF & 16 & 63.06 & 56.6 & 68.89 & 1.16 & 14 & 73.88 & 57.9 & 74.64 & 7.41 \\
\hline HAF & 16 & 9.869 & 7.8 & 12.9 & 1.16 & 14 & 11.49 & 7.8 & 14.84 & 2.05 \\
\hline UBL1 & 16 & 110.35 & 94.1 & 126.36 & 11.04 & 14 & 130.15 & 115.97 & 146.26 & 9.91 \\
\hline UBL2 & 16 & 75.70 & 63.1 & 89.58 & 6.62 & 14 & 79.99 & 67.3 & 88.9 & 7.51 \\
\hline BBL1 & 16 & 47.72 & 30.2 & 58.02 & 6.58 & 14 & 53.67 & 30.9 & 62.88 & 8.83 \\
\hline BBL2 & 16 & 28.64 & 19.10 & 36.7 & 4.06 & 14 & 33,72 & 28.38 & 37.46 & 2.88 \\
\hline LCP & 16 & 30.09 & 23.52 & 35.38 & 3.78 & 14 & 30.81 & 25.34 & 37.79 & 3.92 \\
\hline
\end{tabular}

Note: $\mathrm{M}=$ Mean, $\mathrm{SD}=$ Standard Deviation, Min=Minimum value, and Max=Maximum value

Table 2. T-test results of morphometric characters of male and female $M$. singaringan

\begin{tabular}{|c|c|c|}
\hline \multirow{2}{*}{$\begin{array}{l}\text { Morphometric } \\
\text { character }\end{array}$} & \multicolumn{2}{|c|}{ Male and female (t-test) } \\
\hline & $\mathbf{T}$ & Sig (2-tailed) \\
\hline TL & 1.925 & .064 \\
\hline SL & $2.700 * *$ & .012 \\
\hline HL & $6.459 * *$ & .000 \\
\hline ED & 0.058 & .954 \\
\hline POD & $5.644 * *$ & .000 \\
\hline PDDF & 1.959 & .060 \\
\hline PDAF & $5.871 * *$ & .000 \\
\hline $\mathrm{Bh}$ & 1.772 & .087 \\
\hline $\mathrm{BH}$ & $5.723 * *$ & .000 \\
\hline DFL & 1.103 & .279 \\
\hline $\mathrm{HDF}$ & $4.982 * *$ & .000 \\
\hline PFL & -0.737 & .467 \\
\hline HPL & $5.097 * *$ & .000 \\
\hline VFL & -.093 & .926 \\
\hline HVL & .009 & .553 \\
\hline AFL & 0.146 & .089 \\
\hline HAFL & 0.041 & .331 \\
\hline BAF & $5.126 * *$ & .000 \\
\hline $\mathrm{HAF}$ & $3.997 * *$ & .000 \\
\hline UBL1 & $5.136 * *$ & .000 \\
\hline UBL2 & 1.664 & .107 \\
\hline BBL1 & $2.107 * *$ & .044 \\
\hline BBL2 & $3.889 * *$ & .001 \\
\hline LCP & 0.510 & .614 \\
\hline
\end{tabular}

Note: Significantly different Sig <0.05; *; Sig <0.001; **
Table 3. Relation of morphometric characters and growth patterns of male and female $M$. singaringan with their total length

\begin{tabular}{|c|c|c|c|c|}
\hline \multirow{2}{*}{$\begin{array}{c}\text { Morpho- } \\
\text { metric } \\
\text { character }\end{array}$} & \multicolumn{2}{|l|}{ Female } & \multicolumn{2}{|l|}{ Male } \\
\hline & $\begin{array}{l}\text { Regression } \\
\text { parameters }\end{array}$ & $\begin{array}{l}\text { Slope } \\
\text { (b) }\end{array}$ & $\begin{array}{l}\text { Regression } \\
\text { parameters }\end{array}$ & $\begin{array}{c}\text { Slope } \\
\text { (b) }\end{array}$ \\
\hline PS & $\mathrm{Y}=26.274+0.647 \mathrm{TL}$ & AN & $\mathrm{Y}=24.233+0.630 \mathrm{TL}$ & AN \\
\hline TK & $Y=-13.846+0.312 \mathrm{TL}$ & AN & $\mathrm{Y}=3.004+0.111 \mathrm{TL}$ & AN \\
\hline $\mathrm{DM}$ & $\mathrm{Y}=3.951+0.006 \mathrm{TL}$ & AN & $\mathrm{Y}=1.143+0.021 \mathrm{TL}$ & $\mathrm{AN}$ \\
\hline JMM & $Y=-2.156+0.085 \mathrm{TL}$ & AN & $Y=-0.943+0.065 T L$ & AN \\
\hline JMSP & $\mathrm{Y}=3.320+0.245 \mathrm{TL}$ & AN & $\mathrm{Y}=11.026+0.194 \mathrm{TL}$ & AN \\
\hline JMAF & $\mathrm{Y}=23.464+0.278 \mathrm{TL}$ & AN & $\mathrm{Y}=7.366+0.317 \mathrm{TL}$ & AN \\
\hline $\mathrm{h}$ & $\mathrm{Y}=-3.094+0.104 \mathrm{TL}$ & AN & $Y=-6 . .928+0.124 T L$ & AN \\
\hline $\mathrm{H}$ & $\mathrm{Y}=-11.113+0.270 \mathrm{TL}$ & AN & $Y=-14.057+0.243 T L$ & AN \\
\hline PDSP & $\mathrm{Y}=2.959+0.082 \mathrm{TL}$ & AN & $\mathrm{Y}=-1.734+0.1 / 08 \mathrm{TL}$ & AN \\
\hline TSP & $\mathrm{Y}=6.113+0.154 \mathrm{TL}$ & AN & $\mathrm{Y}=3.509+0.146 \mathrm{TL}$ & AN \\
\hline PDSD & $\mathrm{Y}=2.088+0.017 \mathrm{TL}$ & AN & $Y=-3.356+0.050 \mathrm{TL}$ & AN \\
\hline TSD & $\mathrm{Y}=6.478+0.106 \mathrm{TL}$ & AN & $\mathrm{Y}=9.468+0.072 \mathrm{TL}$ & AN \\
\hline PDSPr & $Y=-0.758+0.026 \mathrm{TL}$ & AN & $Y=-3.562+0.043 \mathrm{TL}$ & AN \\
\hline TSPr & $Y=-7.760+0.162 \mathrm{TL}$ & AN & $Y=0.601+0.133 \mathrm{TL}$ & AN \\
\hline PDSA & $Y=-2.531+0.079 \mathrm{TL}$ & AN & $\mathrm{Y}=-2.948+0.080 \mathrm{TL}$ & AN \\
\hline TSA & $Y=-6.490+0.134 T L$ & AN & $\mathrm{Y}=6.433+0.079 \mathrm{TL}$ & AN \\
\hline PDAF & $\mathrm{Y}=23.538+0.257 \mathrm{TL}$ & AN & $Y=9.560+0.293 \mathrm{TL}$ & AN \\
\hline TAF & $Y=-2.874+0.073 \mathrm{TL}$ & AN & $Y=-4.531+0.075 \mathrm{TL}$ & AN \\
\hline PSA1 & $\mathrm{Y}=66.585+0.324 \mathrm{TL}$ & AN & $\mathrm{Y}=55.536+0.300 \mathrm{TL}$ & AN \\
\hline PSA2 & $\mathrm{Y}=25.559+0.278 \mathrm{TL}$ & AN & $Y=-1.797+0.424 \mathrm{TL}$ & AN \\
\hline PSB1 & $\mathrm{Y}=1.350+0.267 \mathrm{TL}$ & AN & $\mathrm{Y}=28.028+0.108 \mathrm{TL}$ & AN \\
\hline PSB2 & $\mathrm{Y}=17.376+0.083 \mathrm{TL}$ & AN & $Y=-10.133+0.212 \mathrm{TL}$ & AN \\
\hline JASPE & $\mathrm{Y}=41.030-0.052 \mathrm{TL}$ & AN & $Y=48.470-0.101 \mathrm{TL}$ & AN \\
\hline
\end{tabular}
Note: $\mathrm{b}<1$ is allometric negative (AN) 
Research of Ulicevic et al. (2018) on European perch fish (Perca fluviatilis) from Cyprinidae family has obtained 7 out of 19 morphometric characters as discriminators for male and female fish, namely, head length, periorbital distance, predorsal distance of first dorsal fin, predorsal distance of second dorsal distance, first dorsal fin height, second dorsal fin height, and pectoral fin length. Periorbital distance and predorsal distance of first dorsal fin characters showed very significant differences $(\mathrm{P}<0.001)$. Head length, predorsal distance of second dorsal distance, and second dorsal fin height showed significant differences ( $P$ $<0.01$,) while first dorsal fin height and pectoral fin length showed significant differences between two sexes ( $P$ $<0.05$ ) (Ulicevic et al. 2018). In addition, in Amphiprion perideraion, there are 7 of 15 morphometric characters that distinguish sexual dimorphism, including body depth, direct distance between the anterior edge of the upper lip and the posterior of the last dorsal fin, above eye to origin of dorsal fin, above eye to origin of pelvic fin, tip of dorsal fin to anal fin, tip of dorsal fin to the tip of anal fin, tip of dorsal fin to the tip of caudal fin (Abol-Munafi et al. 2011). The direct distance between the anterior edge of the upper lip was very significantly different $(\mathrm{P}<0.001)$ while the body depth was significantly different $(\mathrm{P}<0.05)$.

Various studies on sexual dimorphism and morphometric characters mentioned above have shown the data of morphology differences between two sexes in several species of fish. It confirms that morphometric variations in some species of fish are reflection of different adaptations by fish to the environment (Jawad and AlJanabi 2016), food (McGee and Wainwright 2013), type of prey (Reimchen and Nosil 2004), and/or other abilities in their habitat. The detected morphometric variations are form of morphological adaptation to competition for food or to swimming migration and habitat control (Turan and Basusta 2001; Zimmerman et al. 2009; Herler et al. 2010; Lima et al. 2012), and to ecological selection (Schluter 2001; Cott et al. 2013; Zahorska et al. 2013).

In this study, the sexual dimorphism of $M$. singaringan fish based on morphometric characteristics is strongly influenced by the value of the condition and the relatively good water quality of the River Klawing (data not shown). Value of condition factors is related to food availability (Blackwell et al. 2000) and habitat conditions (Richter 2007), and gonadal development (Ayo-Olalusi 2014). Heltonika (2009) also reported that the size of first mature $\mathrm{M}$ gonads was $14.89 \mathrm{~cm}$ and the gonadal maturity was related to the composition of food in the stomach. Energy deposits from food are good for growth, gonad maturation until the spawning process is stored in several organs such as the back muscles, adipose fin, and viscera. Thus, fin adipose is one of the morphometric characters of the singaringan sexual dimorphism marker. In other Mystus species such as Mystus vittatus, M. cavasius, and $M$. blekeeri, their morphometric characteristics are influenced by climate, geographical factors and availability of nutrients in their habitat (Chakravorty et al. 2016), and on fish from other Bagridae families, Hemibagrus nemurus ecology and human activities (Aryani et al. 2013). In fish from the Cyprinidae family, Perca fluviatilis, its morphometric characters are influenced by nutritional diets (Ulicevic et al. 2018) and in Labeo calbasu, they are caused by environmental changes (Hossain et al. 2010), while in Mystacoleucus padangensis, they are influenced by current velocity (Nofrita et al. 2015). Referring to unpublished data and a number of previous studies, nutritional or food availability factors greatly influenced morphometric characters and could eventually show $M$. singaringan sexual dimorphism markers

Morphometric characters as discriminators for $M$. singaringan in this study, such as height of dorsal fin and height of pectoral fin, are suspected to be related to swimming and hunting ability. The same notion is reported by Lenarz and Echeverria (1991), who have stated that the character of pectoral fin of Sebastes fish is related to swimming and hunting ability, while the characters of upper barbeus length 1 , bottom barbeus length 1 , and bottom barbeus length 1 are related to the ability to detect prey. The base length of adipose fin and the height of adipose fin are thought to be related to energy storage. Heltonika (2009) has said that adipose fin is energy storage for growth and reproduction. Jawad and Al-Janabi (2016) have reported that Silurus triostegus in Shatt al-Arab River have larger mouth, including larger upper jaw and lower jaw, than S. triostegus in Tigris River. This larger upper jaw and lower jaw indicate that $S$. triostegus usually eat large-sized prey. Georgakopoulou et al. (2007) have also informed that in sea bass fish, the change in water temperature greatly affected morphometric characters of head length and head depth, caudal peduncle, and body depth. The same phenomenon also occurs in swordtail fish or Xyphophorus hellerii (Eagderi et al. 2015) and $S$. triostegus from the Tigris River in Iraq (Jawad and AlJanabi 2016). Low-temperature water condition generally increases water viscosity and water density. Changes in morphometric characters are forms of morphological adaptation by shifting towards a fusiform body shape in order to overcome barriers (Wimberger 1992; Sfakianakis 2011).

Sexual dimorphism growth in female $M$. singaringan was larger than that in male $M$. singaringan. It is shown by the mean values of most morphometric characters measured (Table 1). Female Puntius orphoides from Cyprinidae family (Suryaningsih et al. 2014), female Mystus gulio from Bagridae family (Begum et al. 2008), and female Mystus blekeeri (Musa and Bhuiyan 2006) also have larger body size, compared to its male. Larger body size in female fish is very closely related to reproduction, given egg fecundity that keeps increasing and requires a cavity that is large enough to accommodate ovum (Leveque 1997; Suryaningsih et al. 2014: Ulicevic et al. 2018). However, the case is quite different in the Korean Chub or Zacco koreanus and Sebastes fish. Morphometric characters of male Korean Chub fish are larger than the female. Characters of pectoral fin length IDF-IAF (0.263$0.024)$ and the distance between mouth and eye SNL (0.085-0.007) (Snout Length) of female fish are bigger than those of male fish, while PECL character is larger in male (0.213-0.016) than it is in female (0.195-0.017) (Kim et al. 2008). The same things were also found in Sebastes genus, 
of which male fish are larger in terms of head length, width of orbit, interorbital width, length of upper jaw, longest pectoral fin ray, and longest dorsal spine (Lenarz and Echeverria 1991). Different body size between male and female in some types of fish explains the adaptive process of intrasexual selection, choosing mate and partner competition (Taborsky 1998; Paiva et al. 2013; Zahorska et al. 2013), reproductive strategies (Velasco et al. 2006; Kim et al. 2008; Silva-Junior et al. 2013) and reproduction methods (Anderson 1994).

Morphometric character growth in $M$. singaringan that is linear to its total length has also been found in M. gulio (Begum et al. 2008) and Perca fluviatilis (Ulicevic et al. 2018). On the other hand, the relation between characters growth in top mouth gudgeon or Pseudorasbora parva is different. There is character growth that is linear, linear split, and quadratic split (Zahorska et al. 2013). Characters that are linear to total length in male Pseudorasbora parva are postorbital distance, head depth, predorsal distance, preventral distance, caudal peduncle, pectoral fin length, ventral fin length, and anal fin length. Whereas in female Pseudorasbora parva, characters that are linear to total length are postorbital distance, head depth, predorsal distance, preanal distance, pelvic-ventral, ventral-anal, DaAnal, DP-distance, caudal peduncle ventral, postdorsal distance, postanal distance.

Allometric growth pattern of all morphometric characters of $M$. singaringan is characterized as negative allometric. This result shows that the growth of morphometric characters of $M$. singaringan is slower than the total length. All negative-allometric-type morphometric characters were also found in the S. triostegus (Jawad and Al-Janabi 2016). However, in other types of fish, negative allometric growth pattern was found only in certain characters. For example, in male Perca fluviatilis, negative allometric growth pattern was only found in 7 characters, namely horizontal eye diameter (Oh), anal fin length (IA), length of caudal peduncle (Lpc), second dorsal fin height (hDII), ventral fin length (IV), pectoral fin length (IP), and anal fin height (hA). Whereas in female Perca fluviatilis, there are 5 allometric-negative morphometric characters, namely horizontal eye diameter (Oh), first dorsal fin height (hDI), ventral fin length (IV), pectoral fin length (IP), and anal fin height (hA) (Ulicevic et al. 2018).

The results of determination of $M$. singaringan sexual dimorphism in this study have shown clear morphometric characters and character growth pattern in both male and female $M$. singaringan. This research finding is important and very useful as basic information for future conservation strategies and future plan of mass production in captivity. Of course, further studies on morphology and reproduction are still expected to be conducted in the future.

In conclusion, sexual dimorphism of $M$. singaringan is in standard length (SL), head length (HL), the distance from the muzzle to the eyes, the distance from the muzzle to adipose fin, the height of the dorsal fin, the maximum height, the height of the pectoral fin, the base length of adipose fin, height of fin adipose, upper barbeus length, bottom barbe length 1 , and bottom barbeus length 1 . Morphometric characters are strongly influenced by nutrients and energy obtained from nutrients influences linear growth patterns of measured morphometric characters, so they can eventually be used as a marker of sexual dimorphism.

\section{ACKNOWLEDGEMENTS}

We would like to thank the Ministry of Research, Technology and Higher Education of the Republic of Indonesia for the scholarship support.

\section{REFERENCES}

Abol-Munafi AB, Sarmiza S, Norazmi-Lokman NH, Abduh MY. 2011. Sexual dimorphism on the morphometric characteristics of pink skunk clownfish, Amphiprion perideraion. Proc 9th Int Symp Reprod Physiol Fish, Cochin, India, 9-14 August 2011.

Anderson M. 1994. Sexual Dimorphism. University of Princeton Press, New Jersey.

Ariyanto D, Imron. 2008. Morphometrics analysis and genetic diversity in the strain of Carp (Cyprinus carpio). J Fish 10 (1): 53-63.

Aryani N, Nuraini, Suharman I. 2013. Morphological characterization of green catfish (Hemibagrus nemurus) aquatic habitat on the different method based truss morphometrics. J Fish Aquat 4: 139-142.

Aryani N, Hasibuan S, Mardiah A, Syandri H. 2017. Morphometric characteristic of Asian Catfish, Hemibagrus wyckii (Blekeer, 1858) (Bagridae), from the Riau Province of Indonesia. Pak J Biol Sci 20 (8): 282-289.

Ayo-Olalusi CI. 2014. Length-weight relationship, condition factor, and sex ratio of African mud catfish (Clarias gariepinus) reared in flowthrough system tanks. J Fish Aquat Sci 9(5): 430-434.

Begum M, Al Mamun A, Islam ML, Alam MJ. 2008. Morphometric characters and their relationship in estuarine catfish. J Bangladesh Agric Univ 6(2): 349-353.

Blackwell BG, Brown ML, Willis DW. 2000. Relative weight (Wr) status and current use in fisheries assessment and management. Rev Fish Sci 8: $1-44$.

Chakravorty K, Pathak J, Goswarni. 2016. Study of the morphometric and meristic analysis of three Mystus species from the Chandubi Beel, Kamrup district, Assam. Int J Life Sci Sci Res 2: 478-487.

Cott PA, Johnston TA, Gunn JM. 2013. Sexual dimorphism in an underice spawning fish: the turbot (Lota lota). Can J Zool 91: 732-740.

Dahruddin H, Hutama A, Busson F, Sauri S, Hanner R, Keith P, Hadiaty R, Hubert N. 2016. Revisiting the ichtyodiversity of Java and Bali through DNA barcodes: taxonomy coverage, identification accuracy, cryptic diversity and identification of exotic species. Mol Ecol Resour. DOI: 10.1111/1755-0998.12528.

Dimijan GG. 2005. Evolution of sexuality: biology and behaviour. Proc Baylor Univ Medical Center 18: 244-258.

Eschmeyer WN, Fong JD. 2015. Species by Family/Subfamily in the Catalog of Fishes. California Academy of Sciences, San Fransisco, CA, USA.

Esmaeili HR, Sayyadzadeh G, Chermahini MA. 2017. Sexual dimorphism in two catfish species, Mystus pelusius (Solander 1794) and Glyptothorax silviae Coad, 1981 (Teleostei: Siluriformes). Turk J Zool 41: 144-149.

Eagderi S, Poorbagher H, Parsazade F, Mousavi-Sabet H. 2015. Effects of rearing temperature on the body shape of swordtail (Xiphophorus hellerii) during the early development using geometric, morphometrics. Poeciliid Res 5: 24-30.

Georgakopoulu E, Sfakianakis DG, Kouttouki S, Divanach P, Kentouri M, Koumoundourus G. 2007. The influence of temperature during early life on phenotypic expression at later ontogenic stages in sea bass. $\mathrm{J}$ Fish Biol 70: 278-291.

Heltonika B. 2009. Food study and its relationship with reproduction of Senggaringan fish (Mystus nigriceps) in Klawing River, Purbalingga, Central Java. [Thesis]. Institut Pertanian Bogor, Bogor. [Indonesian]

Herler J, Kerscbaumer M, Mitteroecker P, Postl L, Strumbauer C. 2010. Sexual dimorphism and population divergence in the Lake Tanganyika cichlid fish genus Tropheus. Front Zool 7 (4): 1-10. 
Hossain MAR, Nahiduzzaman M, Saha D, Khanam MUH, Alam MS 2010. Landmark-based morphometrics and meristic variations of the endangered carp, Kalibaus Labeo calbasu, from stocks of two isolated rivers, the Yamuna and Halda and a hatchery. Zool Stud 49: 566-563.

Hubert N, Kadarusman, Wibowo A, Busson F, Caruso D, Sulandari S, Nafiqoh N, Pouyaud L, Ruber L, Avare JC, Herder F, Hanner R, Keith P, Hadiaty RK. 2015. DNA Barcoding Indonesian Freshwater Fishes: Challenges and Prospects. DNA Barcodes 3: 144-169.

Jawad LA, Al-Janabi MIG. 2016. Morphometric characteristics of catfish Silurus triostegus (Heckel, 1843) from the Tigris and Shatt Al-Arab rivers, Iraq. Croat J Fish 74: 179-185.

Kim Y, Zhang C, In-Seok P, Jonghun N, Paul O. 2008. Sexual dimorphism in morphometric characteristics of Korean Chub Zacco koreanus (Pisces, Cyprinidae). J Ecol Field Biol 31 (2): 107-113.

Lenarz WH, Echeverria TW. 1991. Sexual dimorphism in Sebastes. Environ Biol Fish 30: 71-80.

Levitan DR. 2005. Sex-spesific spawning behavior and its consequences in an external fertilizer. Am Nat 165 (6): 682-694

Lima ARA, Barletta M, Dantas DV, Possato FE, Ramos JAA, Costa MF 2012. Early development and allometric shifts during the ontogeny of a marine catfish (Cathorops spixii-Ariidae). J Appl Ichtyol 28: 217 225.

Maurya AK, Prasad L, Kumar R, Khan S. 2018. Morphometric relationships and meristic characteristics of ticto babr Pethia ticto (Hamilton, 1822) from Gomti River, Uttar Pradesh. J Entomol Zool Stud 6 (2): 1877-1880.

McGee MD, Wainwright PC. 2013. Sexual dimorphism in the feeding mechanism of three spine stcikle back. J Exp Biol 216: 835-840.

Minos G, Katselis G, Kaspiris P, Ondrias I. 1995. Comparison of the change in morphological pattern during the growth in length of the grey mullets Liza ramada and Liza saliens from Western Greece. Fish Res 23: 143-155.

Musa ASM, Bhuiyan. 2006. Determination of sexual dimorphism in Mystus bleekeri. J Zool Rajashi Univ 25: 65-66.

Nahar A, Chaklader R, Hanif A, Islam A, Siddik MAB. 2018 Morphometric measurement and sexual dimorphism of Barramundi Lates calcarifer (Bloch, 1790) from the Coastal Rivers Adjoining Bay of Bengal. J Fish Aquat Sci 13 (1): 21-28.

Nofrita D, Syandri H, Tjong DH. 2015. Morphological differentiation between Bilih fish (Cyprinidae, Mystacoleucus padangensis, Blekeeri) in Singkarak Lake and Anal River, West Sumatra, Indonesia. J Entomol Zool Stud 3: 171-175.

Nugroho ED, Ibrahim, Rahayu DA, Rupa D. (2016). Morphology study of Mudskipper fish (Gobiidae: Oxudecinae) as an effort to characterize the local biodiversity of Tarakan Island. Harpoon Borneo J 9 (1):46 57. [Indonesia]

Paiva LG, Prestrelo L, Sant'Anna KM, Vianna M. 2013. Biometric sexual and ontogenic dimorphism on the marine catfish Genidens genidens (Siluriformes, Ariidae) in a tropical estuary. Latin Am J Aquat Res 43 (5): 895-903.
Pramono TN, Arfiati D, Widodo MS, Yanuhar U. 2017. Identification of Mystus fish with genetic approach. Sumberdaya Akuatik Indopasifik J 1 (2): 1-9. [Indonesia]

Reimchen T, Nosil P. 2004. Variable predation regimes predict the evolution of sexual dimorphism in a population of threespine stickleback. Evolution 58 (6): 1274-1281.

Richter TJ. 2007. Development and evaluation of standard weight equation for bridgelip sucker and largescale suckers. North Am J Fish Manag 27: 936-939.

Schluter D. 2001. Ecology and the origin of species. Trends Ecol Evol 16(7): 372-380

Sfakianakis DG, Leris I, Laggis A, Kentouri M. 2011. The effect of rearing temperature on body shape and meristic characters in Zebrafish Danio rerio juveniles. Environ Biol Fish 92: 197-205.

Shaurabh S, Sridhar N, Barlya G, Hemaprasanth, Raghavendra CH, Ragunath M, R and Jayasankar P. 2013. Sexual dimorphism in fishes. Aqua Int November 2013: 30-32.

Silva-Junior DR, Carvalho DMT, Vianna M. 2013. The catfish Genidens genidens (Cuvier, 1829) as a potential species in Brazilian estuarine waters. J Appl Ichtyol 9 (6): 1297-1303.

Suryaningsih S, Sagi M, Kamiso HN, Hadisusanto S. 2014. Sexing in the red chick barb Puntius orphoides (Valenciennes, 1863) by using truss morphometrics method. Biosfera 31 (1): 8-16. [In Indonesian]

Taborsky M. 1998. Sperm competition in fish: "bourgeois" males and parasitic spawning. Trends Ecol Evol 13: 222-227.

Turan C, Basusta N. 2001. Comparison of morphometric character of twaite shad (Alosa fallax nilotica, Geoffroy Saint-Hilaire, 1808) among three areas in Turkish Seas. Bull Fr Peche Piscic 362/363: 1027-1035.

Ulicevic J, Mrdak D, Talevski T, Milosevic D. 2018. Sexual dimorphism of European Perch, Perca fluviatilis Linnaeus, 1758 from Lake Skadar (Montenegro) based on morphometric characters. Turk J Fish Aquat Sci 18:343-349.

Velasco G, Reis EG, Vieira JP. 2006. Calculating growth parameters of Genidens barbus (Siluriformes, Ariidae) using length composition and age data. J Appl Ichtyol 23 (1): 64-69.

Wimberger PH. 1992. Plasticity of fish body shape. The effects of diet, development, family and age in two species of Geophagus (Pisces: Cichlidae). Biol J Linn Soc 45: 197-218.

Zahorska E, Blazova M, and Surova M. 2013. Morphology, sexual dimorphism and size at maturation in top mouth gudgeon (Pseudorasbora parva) from the heated Lake Lichenskie (Poland). Knowledge Manag Aquat Ecosys 411 (7): 1-10.

Zar JH. 1999. Biostatistical analysis. Fourth ed. Prentice Hall Inc, New Jersey. Pp 663

Zimmerman MS, Schmidt SN, Kruefer CC, van der Zanden MJ, Eshenroder RL. 2009. Ontogenetic niche shifts and resource partitioning of lake trout morphotypes. Can J Fish Aquat Sci 66: 1007-1018. 